\title{
Coherence, Mutual Assurance and the Rationale for a Treaty
}

\author{
SHELDON LEADER
}

My aim here is to explore the links between two leading reasons for having a binding treaty on business and human rights: the goal of achieving policy coherence and the goal of achieving mutual assurance between states. These two objectives can interact with one another, and their interaction is not usually investigated. Doing so can help shape the design of a treaty in a more promising direction than it might otherwise take. It will also reveal how a treaty is a more urgent need than is often acknowledged. The text is followed by proposed sections in a treaty that reflect the argument.

\subsection{Policy Coherence as a Goal}

As the UN Secretary-General urged in his Report on the post-2015 sustainable development agenda, there is a need to remedy the '... policy incoherence between current modes of international governance in matters of trade, finance and investment on the one hand, and our norms and standards for labour, the environment, human rights, equality and sustainability on the other and to ensure investment policies that are in line with the Guiding Principles.' ${ }^{1}$ Doug Cassel and Anita Ramasastry, in their recent excellent portrayal of the potential elements in a treaty, point to two levels at which this need for policy coherence is felt: national and international. At the level of national law they remind us that the UN Guiding Principles '... call on States to ensure that their laws and institutions affecting business are coherent with their duty to protect

* I would like to thank the two editors for their project leadership an 2 pntributors to this volume for their insightful comments which have made a substantial difference to the arguments presented in this chapter.

${ }^{1}$ UN Secretary General, 'The Road to Dignity by 2030 - Synthesis Report by the UN Secretary General on the post 2015 Agenda' (A/69/700, paras. 95 and 105). http://docu ments.tips/documents/sg-synthesis-report-road-to-dignity-by-2030.html. 
human rights,' and this points to the need for coherence between human rights norms and '... corporate law and securities regulation, investment, export credit and insurance, trade and labour as well as professional codes regulating the legal profession.' ${ }^{2}$ At the level of international agreements, Cassel and Ramasastry point to the need that '... States ... maintain adequate domestic policy space to meet their human rights obligations when pursuing business-related policy objectives with other States or business enterprises. In this spirit, states might agree to include human rights protections in future investment and trade treaties. They could also agree to add human rights standards to the terms of existing treaties. ${ }^{3}$

\subsubsection{Two Types of Coherence}

All this is well and good, but what are we actually looking for in this call for more policy coherence? It is a need that carries different degrees of normative force. At a minimum, the call for coherence among different branches of the law focuses on the fact that the demand to respect human rights might be present in some sets of norms and missing in others, all within the same legal system. There can be, as in some of the examples to follow, an obligation on a state to respect human rights in one instrument, such as a human rights treaty, and an obligation on the state in another instrument, such as an investment treaty, to do things that the human rights treaty forbids. Those interpreting the investment treaty might be able to avoid formal contradiction between legal obligations here by declaring that the human rights treaty has no relevance to its construction. A treaty linking business and human rights would take aim at this exclusion, stipulating that human rights requirements must explicitly or implicitly form part of the corpus of all legal disciplines regulating business.

Notice, however, that there are two ways of filling out this demand. One approach can aim to secure the presence of the rights in all the right places, but pragmatically leave the interpretation of any given right open to vary with context. States parties to the treaty will have come to their

2 D. Cassel and A. Ramasastry White Paper: Options for a Treaty on Business and Human Rights, Prepared for the American Bar Association, Center for Human Rights, and The Law Society of England and Wales (May 2015) p. 35 https://business-humanrights.org/ sites/default/files/documents/whitepaperfinal\%20ABA\%20LS\%206\%2022\%2015.pdf.

3 Ibid. 
support for the instrument with very different convictions about the ground and extent to which economic actors should be held accountable to society for their activities. Wherever possible, on this approach, solutions to particular cases and problems should be sought by drawing on the least controversial aspects of the fundamental principles linking business and human rights. ${ }^{4}$ It follows that those drafting a future treaty should be content to leave a great deal unsaid: aiming to provide a broad framework of principles that generate the least controversy and within which particular solutions will hopefully emerge in the future. Where there is a clash between the cost of observing human rights norms and attending to business gains, on this pragmatic approach, resolution of the conflict might, depending on where the balance of forces lies, see human rights take second place over operative business interests where the two compete. $^{5}$

A stronger conception of coherence is different. It aims not only to place the term 'human rights' in all relevant parts of the law, but to generate a unified coverage and set of priorities for human rights as they compete with other principles and interests across the norms shaping business activity. These features will be explored below, but at this point it is important to notice a concern that these two approaches to coherence share: a worry about the fragility of consensus around the treaty project. Whereas the first approach, pursuing a milder form of coherence, does so out of a concern to preserve support for the treaty via doing the least to perturb the other legal principles and convictions framing business activity - be they in corporate, investment or trade law - the second approach fears that it is precisely this approach that is a recipe for long-term decline in the support for, and creative shaping of, a place for human rights in economic activity. It favours pressing for principles that may be initially unattractive to one or another party in ongoing dialogues, but which they can be brought to see are credibly anchored in human rights principles that apply in areas other than business activity, and which could be plausibly built upon.

Before looking further at the more ambitious species of coherence, it is important to back up and set it off against the milder form.

4 C. Sunstein, 'Incompletely Theorized Agreements in Constitutional Law' 2007 Public Law and Legal Theory Working Paper No 147, Law School, University of Chicago passim http://ssrn.com/abstract_id=957369.

5 S. Deva, 'Treating Human Rights Lightly?' in Human Rights Obligations of Business S. Deva and D. Bilchitz eds. (Cambridge University Press, 2013), 78 at 100. 


\subsubsection{Looking Further Into the Milder Form of Coherence}

At its most basic, as already said, the call for coherence takes aim at the fact that human rights requirements might be present in some areas of law regulating business activity but absent in others. For example, a state might find itself bound to refrain from applying its changed domestic law to an infrastructure project, where the change is aimed at improving labour conditions, because it had previously signed a stabilization clause in an investment contract by which it promised not to alter applicable law for the lifetime of the project. At the same time, under the terms of a human rights treaty the state may be obligated to make and to apply precisely those legislative changes. ${ }^{6}$ Those adjudicators interpreting the stabilization requirement within the four corners of investment law often ignore these human rights obligations of the state, obliging the latter to pay possibly large amounts of compensation for changing domestic law as its human rights obligations require, but which the investment agreement prohibits. As has been often pointed out, the result can be a harsh burden on poorer states. If a treaty on business and human rights insisted that interpretations of investment agreements had to 'take account' of the potential impact of those agreements on human rights norms binding on a state party, this requirement, even in such a weakly formulated form, could widen the scope of attention of those interpreting investment instruments. It would be an example of mild coherence. The Canada/ Senegal Investment Agreement provides an example. It states that:

Each Party should encourage enterprises operating within its territory or subject to its jurisdiction to voluntarily incorporate internationally recognized standards of corporate social responsibility in their practices and internal policies such as statements of principle that have been endorsed or are supported by the Parties. These principles address issues such as labour, the environment, human rights, community relations and anticorruption. Such enterprises are encouraged to make investments whose impacts contribute to the resolution of social problems and preserve the environment. $^{7}$

In this way, human rights can make their appearance in another domain of law. The appearance in this instrument is indeed modest, being simply

6 On this clash see S. Leader, 'Human Rights, Risks, and New Strategies for Global Investment' (2006) 9 Journal of International Economic Law 657-705.

7 Agreement Between Canada and the Federal Republic of Senegal for the Promotion and Protection of Investments, Article 3 www.international.gc.ca/trade-agreements-accordscommerciaux/agr-acc/fipa-apie/senegal-agreement.aspx?lang=eng. 
an encouragement to business to voluntarily adopt a human rights standard. Nevertheless, it would no longer be possible for someone interpreting and applying the terms of investment law in this treaty to say that a concern for human rights is totally irrelevant to their doing their job. It then becomes legitimate for a tribunal to invoke this part of the Senegal/Canada investment agreement in order to deal with a borderline question of interpretation of the investment contract when, say, the scope of a stabilization clause is unclear. Human rights are brought in from the cold and made potentially relevant to an answer: it is a step towards mild coherence. ${ }^{8}$

With due adjustments, this requirement could migrate from its location in a bilateral investment treaty to a global one - to a treaty on business and human rights - and it could be a provision spread to other fields of law governing relevant commercial activity. Indeed, the prospect of movement towards this minimal level of coherence might be opened by the Transatlantic Trade and Investment Partnership (TTIP). A draft of the investment chapter in the agreement submitted by the EU contains an article stating that:

The provisions of this section shall not affect the right of the Parties to regulate within their territories through measures necessary to achieve legitimate policy objectives, such as the protection of public health, safety, environment or public morals, social or consumer protection or promotion and protection of cultural diversity. ${ }^{9}$

'Human rights' are not explicitly referred to in this draft, unlike the Senegal/Canada investment agreement, but neither are they clearly excluded. If a state defends a departure from the relevant terms of the TTIP Agreement treaty as being justified for the sake of the 'social protection' it allows the state to favour, one of the benchmarks for such

${ }^{8}$ Via a clear statement in the objects clause of an investment agreement, human rights can move from being simply relevant to investment promotion through to having a stronger position. This could, if suitably framed and coordinated with the preamble, give the obligation to respect such rights priority over other goals of the treaty when and if there is a conflict. This would be a step towards what is here termed strong coherence, to be elaborated on below. See the important discussion of this point in in J. Anthony VanDuzer, P. Simons and G. Mayeda (2012) 'Integrating Sustainable Development into International Investment Agreements: A Guide for Developing Countries’ pages 92-94. www.iisd.org/pdf/2012/6th_annual_forum_commonwealth_guide.pdf (Last accessed January 6, 2017).

9 European Commission: Draft Transatlantic Trade and Investment Partnership, Article 2 "Investment and regulatory measures/objectives" Tabled and made public on 12 November 2015. http://trade.ec.europa.eu/doclib/docs/2015/november/tradoc_153955.pdf. 
protection could be the criteria provided by the human rights norms binding on that state. On the other hand, if human rights are not imported by those charged to interpret the TTIP agreement, such that they understand a state party not to be entitled to deploy human rights as part of their social policy objectives, we have a potential failure of minimal coherence: a gap appears between the presence of human rights requirements binding on a state from one source, such as a human rights treaty, and the state's inability to rely on such rights coming from another source in a trade and investment agreement.

Even if this egregious gap were closed via interpretation, mild coherence still permits an interpretation of 'necessity' in the TTIP formulation above in a way that allows a state to pursue its policy of social protection in a way that, from among alternative policy choices reasonably available, does least to hamper the commercial objectives of the treaty: a priority which may conform with orthodox interpretations of trade and investment treaties but, as discussed below, is the opposite of that pursued by principles in human rights instruments. ${ }^{10}$

A final example of a potential role for mild coherence with human rights norms takes us from the state to decision-making by the private commercial company. Here, there can be a clash between a company's 'external' obligation - as an entity - to a local population, and the company directors' 'internal' obligation - owed to the enterprise to work for its best interests as a matter of company law. A recent instance has arisen around the controversial Phulbari open-pit coalmine project in Bangladesh. ${ }^{11}$ At least 40,000 people are predicted to be displaced if the project goes ahead in its present form, with 10,000 due to receive alternative land. The rest of that population is directed towards what the company itself admits is a precarious future in unfamiliar urban environments with a cash sum that studies have shown is likely to dissipate quickly. $^{12}$

${ }^{10}$ See on this point S. Leader 'Human Rights and International Trade' in P. Macrory, et al. (eds.) Understanding the World Trade Organization: Perspectives from Law, Economics and Politics (Springer, 2005) Section 5 (D).

${ }^{11}$ International Accountability Project / World Development Movement, Complaint to the UK National Contact Point under the Specific Instance Procedure of the OECD Guidelines for Multinational Enterprises concerning GCM Resources (UK)Initial assessment of complaint (2013); Final statement (2013) (www.gov.uk); see also Brief by the Essex Business and Human Rights Project (On file with the author).

12 Summary of the Report of the Expert Committee to Evaluate Feasibility Study Report and Scheme of Development of the Phulbari Coal Project, (2007) p. 7 (On file with the author). 
GCM Resources, a UK company developing the project via a subsidiary, was challenged before the OECD's UK National Contact Point to withdraw from or reduce the scale of the mine because of its likely damage to food security, health, shelter and other core rights arising from the Project. ${ }^{13}$ GCM replied that to do so would lead its directors to fail to fulfil their fiduciary obligation under the UK's Companies Act, 2006 to 'promote the success of the company for the benefit of its members [i.e. shareholders - SL] as a whole'. ${ }^{14}$ While the statute adds the requirement that in carrying out this duty to shareholders the directors are to 'have regard to the impact of the company's operations on the community, ${ }^{15}$ there is no mention in the text of human rights violations as guidelines in assessing those impacts. While the company did not ignore the human rights objections lodged by the complainants, its directors felt able to read their obligations under the UK legislation in a way that did not give them significant weight.

The Directors may not have the capacity to surrender the contract. GCM is a UK Company and consequently its Directors are obliged to comply with UK law. The UK Companies Act requires that a director of a company must act in the way that he considers, in good faith, would be most likely to promote the success of the company for the benefit of its members as a whole, albeit taking into account a number of factors. ${ }^{16}$

The UK National Contact Point did not comment on this argument. The issue remains open for it. Once again, human rights are not mentioned in the text of the Companies Act. If they are not imported by interpretation, in the name of coherence, then a gap opens: it is possible that human rights law would condemn Bangladesh for allowing this damaging and poorly compensated displacement of such massive numbers of people. However, on their reading of the relevant UK company law, which the UK National Contact did not explicitly reject, the directors considered that they were obligated to the company to accept that damaging displacement as the price to pay for assigning ultimate priority to shareholder interests.

The arguments advanced in the Phulbari case take us a step further. Notice that the company was willing to admit the potential relevance of

13 Supra n 13 paras. 52-70, at pp. 13-16.

14 The applicable law for the purpose of an OECD National Contact Point hearing was the Companies Act, 2006 s. 172.

15 Ibid. s. 172 (d).

16 GCM Resources plc, Point by Point Response to Complaint under the OECD Guidelines for Multinational Enterprises Appendix II, paras. 9-10, at p. 35. 
human rights to the issues, but once these were taken into account it was argued that the rights still did not have enough strength to displace the fundamental conviction that when a clash emerges between those human requirements and the primacy of shareholder interests, the latter must prevail. In other words, the weight assigned to the rights placed them in a secondary position as compared with shareholder rights, which continued to have primacy. ${ }^{17}$ On the strategy behind the search for mild coherence, this relegation can make sense. Human rights make an entrance into business decision-making, but they do so in a way that does least to upset the core priorities assigned to shareholder interests in corporate law. This could appeal to a strategy of preserving consensus among those with very different conceptions of the legitimacy of corporate power: human rights are admitted as relevant, but a version of the weight of those rights is delivered that is designed to work as smoothly as possible with the pre-existing priorities found in the UK's corporate practice. Over time, this is not likely to be enough for a durable consensus around a treaty, and the reason for this inadequacy merits a closer look.

\subsubsection{Levels of Precision vs Levels of Consensus}

In a recent comment on the role of business in meeting the UN's Sustainable Development Goals, the Institute for Business and Human Rights said that:

The Sustainable Development Goals are based largely on the hope that business really has hitched its wagon to the sustainability locomotive, and fear that a closer look might reveal that it has not. The resulting consensus don't ask, don't tell - signals a temporary alliance of business enthusiasts and sceptics. ${ }^{18}$

This diagnosis signals a wider problem that is fundamental for agendas linking business and human rights. It can be called the paradox of precision. On the one hand, we need to be more precise about the features of human rights that can guide business behaviour in difficult cases. On the other hand, there is an attraction in keeping things agreeably general:

${ }^{17}$ On the distinction between a primary and collateral role for human rights in economic regulation, see S. Leader: 'Collateralism' in R. Brownsword (ed.) Global Governance and the Search for Justice (Hart Publishing: 2005), 53-67.

${ }^{18}$ Institute for Human Rights and Business, State of Play: Business and the Sustainable Development Goals (2015), 16. 
the more these features are spelled out in detail, the greater the risk that this will generate fundamental disagreement among the parties concerned. A provisional consensus risks coming apart as an uneasy business community on one side faces a restive civil society on the other. Yet, at the same time, we need to know enough details of the content and weight of human rights if they are to be effective guides in orienting business activity as framed in such norms as corporate or investment law. Both sides want relative precision and both sides also fear it, since they know that they might disagree over the crucial details precision delivers.

If, in this context, these standards are to be taken seriously the parties confronting one another need to be able to operate by tracing a line between a legitimate, if regrettable, impact on a human right and a violation of that right. Those who want to undertake projects that will disrupt lives, and those who wish to protect populations from such disruption, both want to be able to trace such a line. This demands continually greater precision if human rights are to generate precise interventions able to complement the law that carries on without such norms. At the moment, to warn businesses that human rights are at stake in their operations often opens a door to victims, but does not help them to go through that door. That is, they are not helped towards achieving a just legal outcome any more than they would have been were human rights not to have been mentioned at all. Instead, victims' advocates frequently fall back on the classical law of tort, contract, company law etc. To invoke human rights in such situations is often, once the excitement dies down, to invoke a technically redundant element. A treaty linking business and human rights can help change this state of affairs. It can move the parties along from asking whether a human right is at stake per se in business activity towards asking at what level of strength and detail the right is to operate.

There is no option to stand still here. All sides need a degree of precision necessary to decide convincingly on a concrete case in the light of human rights requirements, and all sides face the prospect of a destructive impasse as time goes on if they push hard for their own version of those requirements. There are then two ways to proceed: one is to hold on to the strategy behind mild coherence and hope that it delivers the concrete results in particular disputes that all sides in those disputes will ultimately endorse as legitimate. Another is to opt for strong coherence. As indicated earlier, the former approach is inclined to aim at the least displacement of the objectives traditionally underpinning corporate and investment law, while bringing human rights into account. In 
doing this, however, there is, despite appearances, a fundamental shift of priorities - and a price to be paid for the shift. Whereas human rights instruments typically allow their guarantees to be overridden by the need to pursue other competing objectives, including commercial ones, they do so by adjusting the pursuit of those objectives in a way that does least damage to the underlying human rights at stake. ${ }^{19}$ The cases and principles examined above do the opposite: the version of human rights protection that is admitted is the one that does the least damage to commercial objectives. Over time, victims confronting this result will see that human rights receive less weight than they do in other domains where they are a central, rather than collateral, part of the agenda. A two-speed result threatens: one giving a stronger role to human rights concerns outside of the regulation of business activity, and the other inside it.

It should be possible to avoid this result by assigning the same weight to a human right across all domains framing business activity: to pursue, that is, strong coherence.

\subsubsection{Towards Strong Coherence}

As indicated earlier, this form of coherence looks to fashion a consistent series of principles capable of reshaping crucial parts of the body of norms, and not just adding another rule to those already present in the corpus. ${ }^{20}$ For this to happen, it is not enough to make sure that the expression 'respect human rights' appears in all the relevant sets of laws governing business activity. The basic principles informing those norms must be ranked and given effect in a consistent way in the light of human rights requirements. This can require re-working certain priorities at the heart of commercial practice. In turn, this shift in priorities can call for re-shaping some of the basic elements in corporate, investment and related areas of the law. This can affect rules such as those defining the company director's fiduciary duty to the company, or the separation of parent and subsidiary corporate liability.

${ }^{19}$ S. Leader, 'Collateralism' supra. n. 19 at 55 and S. Leader, 'Two Ways of Linking Economic Activity to Human Rights' (2005) 185 International Social Science Journal $541 \mathrm{ff}$.

${ }^{20}$ It is a form of consistency central to the work of Ronald Dworkin. See, for example his notion of law's integrity in Law's Empire (Fontana, 1986) chs 6 and 7. 


\subsubsection{Strong Coherence and the Fiduciary Obligations of Company Directors}

What is at stake can be seen in two examples. The first takes us back to the Phulbari coal mine in Bangladesh. Here, to recall, the directors of the mining company GCM were seeing their obligations to the population around the mine through the prism of an overall fiduciary obligation to maximize shareholder value. Even when acknowledging the Companies Act's requirement that they 'have regard' for the impact of the mine on local communities, they shaped the scope of that duty through what they took to be the requirement in the Act that any attention to social impacts must be given in a way that does least dama corporate revenue. For this reason, they dismissed the call for a reduced initial size of the mine, which would have required it to be developed in phases: a measure that would have given local populations more of an opportunity to adjust. That option, the company argued, would go against investor interests, as it would reduce annual revenue even though it would still leave the project profitable. $^{21}$ Even if human rights were admitted in this reasoning, such that they form part of the fiduciary concerns for the well-being of the company as required by UK legislation, that insertion would still allocate those rights to a collateral role. That is, the company could have acknowledged that it has to attend to the rights of the affected population, but it could still insist that a way of respecting those rights had to be found that did least damage to investor returns. The basic priorities in the objectives of corporate law remain intact, with a secondary position assigned to human rights. ${ }^{22}$

A strategy of strong coherence, using as a benchmark the principles underpinning human rights instruments, inverts this order of priorities. While acknowledging that such rights may have to be compromised in order to meet competing commercial demands, it insists that a way has to be found of meeting those demands, among reasonably available alternatives, that does least damage to the rights, not the other way around. ${ }^{23}$ For instance, staying with the example of internal displacement balanced against the economic gains produced by projects such as the Phulbari coal mine, the Office of the United Nations High Commissioner for Human Rights has said that

21 Supra n.

22 See elaborations of this point under 'directions of adjustment' between rights of Justice and the Management of Change' January 200063 Modern Law Review 55-8 (2.) Place of Labour Rights in Foreign Direct Investment' in Global Labor and Employment Law A. Marris and S. Estreicher (eds.) (Kluwer, 2010), 579-596.

23 Sup 21. 
States must give priority to exploring strategies that minimize displacement. Comprehensive and holistic impact assessments should be carried out prior to the initiation of any project that could result in developmentbased eviction and displacement, with a view to securing fully the human rights of all potentially affected persons, groups and communities, including their protection against forced evictions. ${ }^{24}$

The World Commission on Dams looks more closely at the balance between human rights and commercial return. It has formulated guiding principles that can be applied to displacements from land arising from a wide range of activity. It demands that reasons be given explaining '.... why the quantity of land proposed to be acquired is necessary and justified in relation to the purpose of the project. ${ }^{25}$ The 'necessity' of a given use of land must, in the view of the Commission, be set against the requirement that it pursues the least displacing of the alternative project strategies available. This can call for compromise, since the Commission presses for accepting a smaller scale for some projects in return for significant gains to those affected in the local population: which is precisely the approach that the mining company rejected in Phulbari. In relation to dams, for example, the Commission argues that '.. small reductions in height of a large dam may dramatically reduce displacement, with a proportionately much smaller fall in benefits. ${ }^{26}$

The UN Global Compact draws such a line. In its advice about operationalising higher human rights standards, it anticipates that meeting greater demands of this sort can result in significant extra costs to business. It then recommends fixing ' . . . a threshold of losses incurred by an investor, above which the host state will share the economic burden of compliance', while below that threshold the extra costs would be for the investor to bear. ${ }^{27}$

24 UN OHCHR, 'Basic Principles and Guidelines on Development Based Evictions and Displacement' Annex 1 of the report of the Special Rapporteur on adequate housing A/HRC/ 4/18 Para 3 www.ohchr.org/Documents/Issues/Housing/Guidelines_en.pdf (Last accessed 7 January 2017).

25 World Commission on Dams, 'Dams, Displacement, Policy and Law in India' http:// siteresources.worldbank.org/INTINVRES/214578-1112885441548/20480074/ DamsDisplacementPolicyandLawinIndiasoc213.pdf (Last accessed 7 January 2017).

26 Ibid.

27 This is in the analogous context of higher costs resulting from limiting the effect of stabilization clauses in order to allow host states to respect ongoing human rights standards. UN Global Compact, 'Human Rights and Business Dilemmas Forum, "Stabilisation Clauses", Suggestions for Responsible Business,' para 27 available at http://human-rights.unglobalcom pact.org/dilemmas/stabilisation-clauses/\#.Umf6e5ReuXR (Last accessed on 7 January 2017). 
Via this path, human rights standards can penetrate quite far into a company's calculation of costs and benefits. In these statements, special weight is assigned to human rights considerations leading to a call for compromise on the company's search for optimal returns. This could in turn have a strong impact on orthodox understandings in corporate law of directors' fiduciary duty to their company, mentioned earlier. ${ }^{28}$ It is an impact that goes further than the strategy of mild coherence is likely to find comfortable.

At the moment, the positions advanced by the company in the Phulbari case, including those it takes which are open to human rights concerns, express what can be called a two-world view: one set of internal standards links the director and the company, and another quite different set of external standards links the company, as an entity, and the state. Internally, the directors are - they argue - bound as fiduciaries to treat human rights concerns as exceptional and secondary factors: taking them away from their core obligations towards investors. Their allegiance to the short and long-term interests of shareholders leads them to reject the call for scaling down the initial size of the mine, followed by a later phase when the first is completed. Whatever concessions are made by the company to the need to take other measures to respect the human rights of those affected, such as prior consultation with those affected, this measure of size reduction could considerably alleviate the inroad on their basic rights. It is rejected by the company even though no evidence was submitted that it would significantly damage overall profit. Externally, the picture is quite different. The human rights obligations of Bangladesh point in the opposite direction. Its primary duty is to protect its population by requiring the company to look for alternative measures that would have a less damaging impact on human rights. Profitability would have to be adjusted so as to make this possible. The state would then require the company, as an entity, to do what the directors do not consider themselves internally entitled to do under corporate law principles. If the orthodox conception of the director's duty to the company remains in place, while

28 See the analysis of the director's fiduciary duty in this context in D. Bilchitz and L. Ausserladscheider Jonas, 'Proportionality, Fundamental Rights and the Duties of Directors' 2016 Oxford Journal of Legal Studies 1-27; for a differently framed argument see S. Leader, 'Participation and Property Rights' (1999) 21 Journal of Business Ethics 97109; 'Gouvernement d'entreprise et droits des salariés' in S. Leader and P. Lokiec, Pascal, Revue de droit du travail, (Paris: Dalloz, 2008), 3, 201-203 ; S. Leader 'Labour Rights in the World Economy' In L. Blecher et al. (eds.), Corporate Responsibility for Human Rights Impacts (Washington DC: American Bar Association, 2013). 
the company as an entity is also called on to respect human rights, a clash of obligations emerges. Company directors can claim that their fiduciary obligations to shareholders dominate, with the risk - as in Phulbari - that this is thought to prevent their steering the company towards the same degree of respect for human rights that the state must display.

A treaty linking business and human rights can close this gap, as will be argued in Part II. It can provide that the same standards govern the state's duty to protect its population's rights from damage by private actors, the company's duty as an entity, and the directors' own duty to act in the best interest of that company. The benchmark provided by the state's obligation would be carried through into the directors' fiduciary duty to promote the success of their company. All sets of norms would be integrated, with the priority assigned to human rights when balanced against other competing interests. It would be a step towards strong coherence across the collection of norms regulating business activity.

\subsubsection{Strong Coherence and Corporate Structure: The Example of the Corporate Veil}

A second example of the potential in strong coherence moves from deliberations in the boardroom to the place of that boardroom and the company itself within a wider corporate structure. Here, there is another potential threat to human rights that a treaty could address. It emerges in the ever-present problem of the 'corporate veil'. This element of corporate law continues to bedevil the search for a way of making responsibility follow the locus of corporate power. Parent companies are, barring exceptional circumstances and jurisdictions, often treated as legally separate entities from their subsidiaries. Liabilities are usually confined to the subsidiary that caused an accident or signed a commercial contract, while the parent has no more obligation arising from what its subsidiary has done than does any other shareholder in a limited liability company.

At the same time, de facto control over key policies and practices of the subsidiary is usually in the hands of the parent, sometimes accompanied by regular transfers of assets from the subsidiary to head office. If, in this situation, we simply declare that corporations are to 'respect human rights', we don't have enough in hand to know when this classic separation between the liability of parent and subsidiary does and does not contribute to violations of those rights. Invoking human rights concerns takes us no closer to seeing when it is appropriate to pierce the corporate veil, or indeed when it is appropriate to side-step the veil without piercing it by 
increasing the range of a parent company's responsibility for its subsidiary's behaviour via an extension of the parent's duty of care. ${ }^{29}$ Matters are not greatly improved if we add provisions which mention human rights like those in the Canada/Senegal Investment Agreement, seen above. 10 se tells us that enterprises are encouraged in the name, inter alia, of human rights to '... make investments whose impacts contribute to the resolution of social problems and preserve the environment. ${ }^{, 30}$ A good deal more precision is needed if this element of the treaty can be turned to helping answer hard questions about what is and is not to be tolerated in the preservation of parent companies from liability. ${ }^{31}$

It is possible for a treaty linking business and human rights to say more, and with a level of detail that gives human rights real purchase in dealing with potential abuses of the 'corporate veil'. Consider the agreement among member states of the Economic Community of West African States (ECOWAS). The Community has produced a measure that can be seen as a regional and sectorial species of treaty on business and human rights. ${ }^{32}$ The measure, in the form of a directive, provides as part of its formal commitment to human rights that member states are to require of mining companies that they obtain free, prior and informed consent of local communities before exploration begins and prior to each subsequent phase of mining and post-mining operations. Companies are to maintain consultations and negotiations on important decisions affecting local communities throughout the mining cycle. The companies must also set up socio-economic development funds to which mining rights-holders shall contribute by law for the development of new capacity in the affected local communities. ${ }^{33}$

This is a step towards giving priority to human rights concerns that strong coherence demands. As the ECOWAS Directive puts the requirement, ' ... Member States, holders of mining rights and other mining related business entities have a primary ${ }^{34}$ obligation to respect

29 Cf. Chandler v Cape Industries EWCA Civ 525 (25 April 2012).

30 Agreement Between Canada and the Federal Republic of Senegal for the Promotion and Protection of Investments, Article 3 www.international.gc.ca/trade-agreements-accordscommerciaux/agr-acc/fipa-apie/senegal-agreement.aspx?lang=eng.

31 Eor a strong example of a human right iirement of greater scope and depth, see Van Qui) er, Simons and Meyeda, supra n. S. 309-316.

32 WAS Directive C/DIR.3/05/09 on the Harmonization of Guiding Principles and Policies in the Mining Sector, Article 16. See also discussion of the ECOWAS Directive in Mining and Human Rights in Senegal, Amnesty International 2014 www.amnesty.nl/sites/ default/files/public/p4350_senegal_mining_report_-_web_en.pdf.

33 Ibid., Article 16 para $7 .{ }^{34}$ Emphasis mine, SL. 
and promote recognized human rights including the rights of women, children and workers arising from mining activities. ${ }^{35}$ Without wanting to read too much into a single word, this claim of primacy for human rights does give a central rather than a collateral place to human rights on the business agenda.

It is also precise and concrete enough in its requirements that member states are given the guidance about elements of corporate behaviour that must be targeted. The states can in turn re-shape - if necessary by further agreement among themselves - rules in their corporate law necessary to give effect to this primacy of human rights-driven requirements about appropriate levels of consultation and about the establishment of capacitydevelopment funds for the locals affected. In particular, the member states have a basis for turning back to their own corporate laws and amending them so as to hold parent companies liable for claims by victims against subsidiaries arising from violation of these consultation and development fund requirements. In these and allied areas picked out by human rights instruments and principles, the liability could be extended to those companies within the corporate group which have the resources and/or the relevant control to compensate adequately or to prevent damage. ${ }^{36}$ This would not be a total collapse of the separation between parent and subsidiary liability but would instead be an intervention that was precisely targeted, integrating human rights requirements into a principle at the heart of corporate law. It would pursue a strong form of coherence.

If the strong version of coherence sought in these examples is a desirable objective what role might a treaty play in achieving it? This is the next question to consider.

\subsection{Strong Coherence via a Treaty on Business and Human Rights}

The prospects for a treaty depend on who is sitting around the table and on what it is that motivates them to negotiate a treaty in the first place. Consider a classic and important reason for entering into a treaty: the creation of mutual assurance among the parties to the agreement. If states agree on a common set of human rights standards guiding business, such

35 Ibid., Article 15 para 1.

36 For an application of this approach to the liability of the Royal Dutch Shell group, see Corporate Liability In a New Setting: Shell and the Changing Legal Landscape for the Multinational Oil Industry in the Niger Delta, by the Essex Business and Human Rights Project (2012), pp. 5155. http://www.essex.ac.uk/ebhr/activities/default.aspx. 
as those in the UN Guiding Principles, then it makes sense that, once agreed, these standards cease being sites of competition among those states - even as they carry on competing in other ways - on pain of triggering a well-known problem known as the 'race to the bottom'. For, what starts as being a shared view about the desirability of a certain level of human rights protection afforded by business can end up being undermined - not because each state has changed its basic priorities and come to think it fundamentally right to lower that protection, but because without agreed sanctions to enforce the shared view, it is frightened that a competitor will draw inward investment away from it if it does not weaken that commitment. All the concerned states end up worse off - as measured by their own standards - because they cannot trust one another to hold to the standard that they each initially subscribed to: the race to the bottom is on. ${ }^{37}$

\subsubsection{Host State and Home State Concerns}

While this is a well-known problem, it actually comes in several varieties: each with different potential impacts on the design of a treaty and each having a particular impact on the goal of strong policy coherence. The difference is located in the concerns of states that are primarily hosts to inward investment on the one hand and, on the other, those that are primarily home to the companies making such investment. While each might seek competitive assurance against a race to the bottom, they are looking at different threats and at different parties doing the threatening. For example, the states in ECOWAS have been concerned that international mining companies might play one member state off another in choosing the regulatory environment in which the companies find it easiest to work. Having made their initial commitment to protecting human rights at a level of significant detail in the mining industry, the member states are, via this directive, coordinating their efforts via a regional and sector-focused version of a treaty on business and human rights. As one analyst puts it, a key objective of this Directive is 'lessening competition ... between the member states'. ${ }^{38}$ In other words, it aims to remove mutually undermining competition among ECOWAS members over requirements

${ }^{37}$ For an exploration of this phenomenon see Mancur Olson, The Logic of Collective Action: Pubi Goods and the Theory of Groups (Revised edn. Harvard University Press, 1971); Shel 9 eader, Freedom of Association (Yale University Press, 1992), ch. 7.

38 Mayer Drown Recent Legal Developments in the Mining Sector of West African States page 2 www.mayerbrown.com/files/Publication/. 
they impose on business: all the ECOWAS member states wish to impose these requirements, but each member might be tempted to weaken its commitment to doing so out of fear of what its neighbour might do.

While states that are hosts to international mining activity, often in the developing world, share this interest, other states - no less involved in international mining, but as home states in the developed world - share a different interest. Canada and Senegal, for example, do not risk competing with one another for inward investment - not, that is, in the same way that Senegal and Mali might compete. Canada may indeed welcome a measure of regulatory competition between the latter two states as good for Canadian mining interests in the region. On the other hand, Canada does share with, for example, the United States or certain states in the EU an interest in setting similar controls on the responsibilities of the parent companies for their MNCs operating abroad. If one home state jurisdiction is stricter than is the other then they might find that corporate headquarters migrate to the less stringent - with the attendant loss of corporate tax revenue and jobs. ${ }^{39}$

Of course, the differences among home and host states are not quite this stark. Countries normally labelled hosts to the activities of transnational companies may also be homes to large transnational parent companies, such as India and Brazil, and many that are homes to outward investment are also hosts to certain inward investment activities of transnationals. Thus, Senegal might worry about its domiciled parent companies migrating to less regulated environments in the same way that Canada does. Yet, this is unlikely to include the fear that the Senegalese parent will move to Canada, whatever the formalities of a bilateral investment agreement allowing for two-way corporate investment might provide. ${ }^{40}$ Equally, Canada might fear that Senegal can provide a comparatively low level of labour rights protection and so draw employment away from Canada's shores via the latter's businesses transferring some of their operations to the cheaper operating environment. This worry can and does provoke strong reactions from civil society in developed countries, acting to protect

39 There are factors in any given sector that may well deter capital flight from home countries, such as favourable insurance services, tax laws and investment services available to nationals. These would weigh against but do not always eliminate the capital flight concern. I am grateful to Penelope Simons for this point.

40 Agreement between Canada and the Federal Republic of Senegal for the Promotion and Protection of Investments, Article3 www.international.gc.ca/trade-agreements-accordscommerciaux/agr-acc/fipa-apie/senegal-agreement.aspx?lang=eng (Last accessed 7 January 2017). 
labour, health and environmental standards. These issues prompt a search for a floor of mutual guarantees, as seen in the section of the investment agreement between Canada and Senegal mentioned above. ${ }^{41}$ However, a home country in the developed world will nevertheless be concerned that over the wide range of other potential human rights concerns that apply to business, the hands of its companies should not be tied unduly when operating in host countries. Canada might therefore be willing to see a regulatory race to the bottom between host countries in West Africa, for example, anxious to attract inward investment while wanting to avoid such a race between itself and other similarly placed home countries wanting to encourage outward investment for their companies.

Therefore, there are at least two distinct races to the bottom that threaten: one manifested in worries shared among home countries about being undercut as they vie for favourable conditions for their capital-exporting businesses and the second, in distinct worries, shared among host countries about being undercut as they vie for the best terms for their capital-importing activities. It is tempting to deny this by pointing to the fact that both sets of countries largely accept the human rights standards applying to business as set out in the UNGPs. Support by states is overwhelmingly in favour of the Guiding Principles, and this can seem like an inducement to take human rights off the table as items of competition between all states, without dividing them between home and host states. However, this accord on the Principles may deliver less than it appears to: within that envelope of agreement there is room for strong divergence about the scope and weight of a relevant human right when deployed to deal with a particular type of situation. When countries' interests are as strongly differing as are those in our examples, consensus among them risks unravelling if pushed too hard to solve particular problems. There arises the paradox of precision referred to earlier. Precision is simultaneously necessary and is an obstacle: it is necessary if the promise of mutual assurance against being undercut is to have any efficacy in stopping a race to the bottom, and it is an obstacle since the level of consensus among states needed to make progress is difficult to obtain. How, if at all, can a treaty help here?

Both home and host countries might reach agreement on what was identified earlier as a mild level of coherence. They might eventually agree, to go back to an earlier example, that human rights obligations should be included in the fiduciary obligations that directors owe to their

41 Canada - Senegal Investment Agreement, Article 16 supra n. 9. 
companies. However, these countries are likely to disagree strongly over what the concrete impact of human rights standards should be on the content of that fiduciary obligation. Imagine that ECOWAS members were to propose, as a provision of a global treaty to which Canada was asked to agree, that states parties to the treaty impose on companies within their jurisdiction an obligation corresponding to the detailed requirements that ECOWAS has enacted for mining companies. This would include the duty to maintain consultations and negotiations on all important decisions affecting local communities throughout the mining cycle. ${ }^{42}$ Canada may well resist, preferring to fall back on the precedent of the more general, voluntary provisions of its Investment Agreement with Senegal stating, as we have seen it do, that '... Each Party should encourage enterprises operating within its territory or subject to its jurisdiction to voluntarily incorporate internationally recognized standards of corporate social responsibility in their practices and internal policies ..., ${ }^{43}$

This has the ingredients of an impasse between host and home states: an impasse which leads many to predict an interminable wait before the key terms of a treaty can be agreed by all concerned. However, the parties and the issues they face are not standing still. While debates about a global treaty go on, Senegal, other member states in ECOWAS and many others in mineral-rich areas face pressures - at times amounting to violent protests - from local populations evicted by mining activity from their homes, suffering damage to their health and family disintegration. Domestic social and political pressures could lead these states to insist, in the name of human rights, on detailed matters of consultation and protection for local populations - equivalent to those that the agreement to produce the Mining Directive contains. If there were no such mutual undertaking, these states would have less confidence in pressing companies investing in their economies to take the more costly route of spending on measures that can avoid social damage in advance, as the Directive does. Without the mutual assurance that the Directive is designed to help deliver, the state is thrown back onto the blunt instrument of suppressing protest as it emerges. That can be all that remains in its reserve of measures. These states face urgent needs in their local populations that other states that are home to the major enterprises do

42 They could back up their argument by pointing to the resemblance between their consultation requirements and those of the IFC in its performance standards. See IFC Perform Standard 1.

43 Supra n! 
not face. The latter are therefore likely to be more cautious about entering into a tight, enforceable human rights requirement. They are thus likely to resist strong coherence.

In short, the members of ECOWAS, and other host states similarly situated, have good reason to opt among themselves for strong rather than weak coherence on human rights standards. They have particular reason to try to close the gap between broad human rights provisions and their concrete implications in the realm of business activity. The prospect for strong coherence is greater if the range covered by a treaty is regional and/or sectorial rather than if it is global. On the other hand, the pursuit of a global treaty will correspondingly weaken the attractions of a policy of strong coherence, forcing us to be content to achieve the milder version.

Much turns on the choices to be made between these two strategies. We can either aim at strong coherence or, going in the opposite direction, human rights will move into a 'two-speed' regime mentioned earlier: having greater strength outside of the world of business than they do within that world. If we go down the latter path we fuel disillusionment, together with the slow atrophy of support by some and the increasingly cynical deployment of the label 'human rights' by others.

\subsection{Conclusion}

This argument supports the construction of a treaty on business and human rights built on consensus among an initially narrow scope of parties within a given region and/or sector. It is a consensus that can gradually spread beyond those borders - particularly once home countries realize that host countries are making robust treaties among themselves that carry consequences for the former. The initial benefits of this strategy should show themselves quickly. The mutual assurance such a treaty can provide could give those hosts facing similar international commercial pressures to lower social standards a basis for resisting doing so - as a group with its members able to count on one another. At the same time, it is such smaller scale treaties that should be able to encourage host governments to give the human rights they guarantee their proper content and weight in the name of coherence with human rights standards developed in other areas of law and policy - a coherence that is not shrunken due to these rights being introduced into the unfamiliar terrain of business activity. Without support from such an instrument, national efforts to give effect to the UN Guiding Principles are likely to be weakened by the 
persistent fear that one's competitors are not going to live up to the standards they profess to embrace. If we are to make further progress nationally, we need mutual assurance internationally - but on a scale that allows nations similarly placed in the world economy to move ahead with greater confidence. Such a treaty fills an urgent need.

\subsection{Draft Treaty Clauses Relating to Elements in the Chapter}

The following draft provisions are directed at the goals of strong coherence and mutual assurance that have been discussed.

\subsubsection{Preamble (Elements)}

Whereas it is essential that a Treaty be able to provide assurance that each state party undertakes to the others that it will observe the Treaty's Wheren $\Omega_{t}^{s}$,

Wher $\mathrm{t}_{\mathrm{t}}$ is recognised that appropriate sanctions be designed and deployed for failure to respect the said undertaking,

Whereas it is the object and purpose of this Treaty to govern the relationship between states, non-state actors in the economy, and natural persons by applying national and international human rights law, and

Whereas human rights law is to be given priority wherever it is in conflict with other bodies of law governing business activity ...

\subsubsection{General Interpretive Protocol (Elements)}

The parties agree that the body of law included in Annex I shall be interpreted in accordance with the requirements of instruments included in Annex II together with relevant provisions of customary international law. [Note: Annex I includes relevant provisions of regulating business activity, including but not limited to corporate, labour, competition, intellectual property, data management and investment law. Annex II includes all elements of national and international human rights law applicable to the parties].

The object and purpose of the provisions in Annex 1 shall have added to them the object and purpose of giving effect to the rules and principles of the provisions in Annex 2. Where the provisions in Annex 1 are in conflict with those of Annex 2, priority is to be given to Annex 2. For the avoidance of doubt, the parties must find a method of implementing the provisions of Annex 1 that, from among reasonably available alternatives, 
imposes the least burden on and/or provides the greatest opportunity to further the rights provided in Annex 2.

Any party to this Treaty can bring a complaint to [an Authority] alleging failure by another party to respect the requirements of the foregoing paragraphs.

\subsubsection{Application to Corporate Laws in Annex 1(Elements)}

The Parties agree to incorporate into their laws relating to companies the following provisions:

Directors must execute their duties in a manner that implements their company's obligation to respect and adequately remedy the rights guaranteed by the provisions in Annex 2 and in compliance with the priority for human rights as provided for the General Interpretive Protocol.

The individual's fiduciary duty to the company of which he or she is director shall include respect for the relevant human rights of all stakeholders.

For associated companies [Note: a term to be defined so as to capture the features of a corporate group], liability for damage to the rights indicated in Annex 2 is to be shared among all associates which are or have been in a position to contribute significantly to compensating and/or preventing that damage. For the avoidance of doubt, where such damage to human rights has happened, no associated company will benefit from limitations on liability for the acts of another associated company which would otherwise apply. 
